5. Khamisy, D. (2006). Edukacja przedszkolna a integracja społeczna [Pre-school education and social integration]. Warsaw, 420 p. [in Polish].

6. Lobocki, M. (2008). Teoria w zarysie [Theory in outline]. Krakow, 359 p. [in Polish].

7. Mikler-Chwastek, A. (2010). Wychowanie i wspieranie rozwoju małych dzieci [Upbringing and supporting the development of young children]. Warsaw, 146 p. [in Polish].

8. Lubomirska, K. (1994). Przedszkole. Rzeczywistość i szansa [Kindergarten. Reality and Chance]. Warsaw, 187 p. [in Polish].

9. Okoń, W. (2004). Nowy słownik pedagogiczny [New pedagogical dictionary]. Warsaw, 466 p. [in Polish].

10. Okon, W. (2009). Wszystko o wychowaniu [Everything about education]. Warsaw, 386 p. [in Polish].
11. Rozporządzenie Ministra Edukacji Narodowej $\mathrm{z}$ dnia 30 maja 2014 r. zmieniające rozporządzenie w sprawie podstawy programowej wychowania przedszkolnego oraz kształcenia ogólnego w poszczególnych typach szkół (Dz. U. z 2014 r., poz. 803) [Regulation of the Minister of National Education of 30 May 2014 amending the regulation on the core curriculum for pre-school education and general education in individual types of schools (Journal of Laws of 2014, item 803)]. Available at: h t t p : / / is a p.sejm.gov.pl/is a p.nsf/ DocDetails.xsp?id=wdu20140000803 [in Polish].

12. Schaffer, H.R. (2004). Psychologia dziecka [Child psychology]. Warsaw, 404 p. [in Polish].

13. Stein, B. (2008). Teoria i praktyka Marii Montessori w szkole podstawowej [Theory and practice of Maria Montessori in primary school]. Kielce, 156 p. [in Polish].

Стаття надійшла до редакції 29.10.2020

УДК 378.147

DOI:

Людмила Бірюк, доктор педагогічних наук, професор, завідувач кафедри педагогіки і психологї початкової освіти Глухівського національного педагогічного університету імені О. Довженка

Сергій Пішун, кандидат педагогічних наук, доцент кафедри педагогіки і психології початкової освіти Глухівського національного педагогічного університету імені Олександра Довженка

\title{
ПАРАДИГМАЛЬНИЙ ПІДХІД У ФОРМУВАННІ КОМУНІКАТИВНОЇ КОМПЕТЕНТНОСТІ МАЙБУТНІХ ФАХІВЦІВ ПОЧАТКОВОЇ ШКОЛИ
}

У статті зроблена спроба теоретичного аналізу парадигмального підходу як сукупності ключових положень та ідей, щзо визнані педагогічною спільнотою в конкретний період і лежать в основі наукових досліджень. Зазначено, щьо формування освітніх парадигм відбувається в процесі освоєння людством різних способів взаємодії зі світом, тому кожна з них відповідає тому чи тому його сприйняттю як педагогічного об' $е к т а$.

Парадигмальний підхід до розвитку особистості в умовах функціонування освітньої діяльності забезпечує новий перцептивно-комунікативний процес спілкування, причому зв 'язки, щчо виникають, не лише повторюють систему функціональних відносин різних компонентів суспільства, а йвзагалі $\epsilon$ його найважливішим вираженням у педагогічному дискурсі.

Ключові слова: комунікативна компетентність; методологія; особистість; парадигмальний підхід; педагогіка; теорія.

Puc. 1. Лim. 8 .

Lyudmyla Biryuk, Doctor of Sciences (Pedagogy), Professor, Head of the Primary Education Pedagogics and Psychology Department Hlukhiv Oleksandr Dovzhenko National Pedagogical University Serhiy Pishun, Ph.D.(Pedagogy), Associate Professor of the Primary Education Pedagogics and Psychology Department Hlukhiv Oleksandr Dovzhenko National Pedagogical University

\section{PARADIGMAL APPROACH TO FORMING COMMUNICATIVE COMPETENCE OF FUTURE PRIMARY SCHOOL SPECIALISTS}

Understanding the paradigmal approach in the history of pedagogy is that the constructing the historical 


\section{ПАРАДИГМАЛЬНИЙ ПІДХДУ ФОРМУВАННІ КОМУНІКАТИВНОЇ КОМПЕТЕНТНОСТІ МАЙБУТНІХ ФАХІВЦІВ ПОЧАТКОВОЇ ШКОЛИ}

and pedagogical process (both practice and theory) is based on a peculiar methodological construct - the pedagogical paradigm. The educational paradigm is understood as a set of key propositions and ideas that have been recognized by the teaching community in a particular period of time and is the basis for scientific research. Forming the education paradigms occurs together with humanity developing by different ways of interacting with the world. Each of the paradigms corresponds to a particular perception of the world and pedagogical objects.

Taking the basis of this category definition, proposed by T. Kuhn, as a recognized by scientific community model for solving scientific problems, native scientists interpreted it for the educational purposes. In a more concrete form, the paradigm of pedagogical education is the reasoning the aims of vocational (professional and pedagogical) education (in our case communicative competence), an explanation of its reasons, and also includes proved ideas about the content and technologies of teaching and the relationship of participants in the pedagogical education system.

Today we see a further activation of this concept:

- a paradigm is a scientific and theoretical, conceptual vision of the world (R. Chellcout);

- a paradigm is the normative methodology of scientific search (G. Bergman);

- the paradigms and theories that are formed in their contexts can specify two main aims: understanding the world (this is provided by the part of the concept that the purpose of explanation is focused on) and helping those who act within this world by providing the models of decisions and their implementation (A. Etzioni).

The paradigmal approach to the developing a personality in the context of the functioning of educational activities provides a new perceptual and communicative process of speaking, and the arisen connections not only repeat the system of functional relations of various society components, but in general it is its most important expression in the pedagogical discourse.

The paradigm changes under the influence of new circumstances (facts) that cannot be explained within it; the paradigm influences methodology and theory, which in turn determine the process of recognition in one area or another of scientific knowledge. Ultimately, the paradigm is concreted in theory.

Keywords: communicative competence; methodology; a personality; paradigmal approach; pedagogy; theory.

$\Pi$ остановка проблеми. Вивчення будьякого аспекту історико-педагогічного процесу вимагає визначення вихідних теоретичних позицій, що в сучасних умовах широкого методологічного плюралізму нерідко викликає труднощі. Сутність парадигмального підходу в історії педагогіки полягає у тому, що конструювання історикопедагогічного процесу (як практики, так і теорії) відбувається на основі своєрідного методологічного конструкту - педагогічної парадигми. Парадигми освіти висувалися різними авторами. Однак останнім часом теоретики освіти почали пропонувати інтегровані наукові парадигми, і це, звичайно, не випадково. У кожен конкретний історичний момент парадигма освіти з властивою їй специфікою відображає світогляд соціуму, ідеологію, що панує у ньому, рівень розвитку педагогічної науки й характеризується відповідним уявленнями суспільства про пріоритетні цілі й завдання освіти, критерії ефективності та результативності освітнього процесу, пізнавальних та інших можливостей особистості. Словник-довідник сучасної загальної освіти визначає парадигму як теорію (або модель, тип постановки проблеми), прийняту за зразок розв'язання дослідницьких завдань [8].

Аналіз останніх досліджень і публікацій. Вивченню парадигмальних підходів у педагогічній освіті присвячені праці Г. Балла, М. Бойченка, С. Гончаренка, 3. Донець, В. Кременя, I. Зязюна, В. Лугового, В. Лутая, Ю. Мальованого, Г. Онкович та ін.), які свідчать про посилення особистісного виміру в педагогічній науці. Так, В. Кремень зазначає, що орієнтація на людину, фундаментальні цінності, рішуча демократизація освіти - ось ті підвалини, на яких повинна базуватися освіта третього тисячоліття. Гармонійно розвинена особистість має бути головною метою й змістом усієї системи освіти $[3,5]$.

Аналіз поняття “парадигма", що використовується в педагогічному контексті, дає підстави виділити підходи до трактування цього терміна. По-перше, це близьке до класичного загальнонаукового розуміння парадигми як моделі наукової діяльності, сукупності норм, критеріїв, стандартів дослідження (Н. Коршунова, В. Краєвський). Прихильники другого напряму в розумінні парадигми трактують їі як основи, ідеї, підходи до проєктування освітніх систем, як зразок у розв'язанні освітніх завдань (Н. Клушина, Г. Корнетов, В. Пилипівський, І. Фомічова).

Синтетичним варіантом розуміння парадигми в першому й другому випадку є трактування педагогічної парадигми як певного стандарту у розв'язанні як наукових, так і освітніх завдань. Чим можна пояснити затребуваність цього терміна в педагогіці? Він не тільки ввійшов до наукового лексикону і часто використовується в науковопедагогічних працях, а й належить до актуальних понять сучасної педагогіки.

Мета статті - визначення й теоретичне осмислення парадигмального підходу в процесі формування комунікативної компетентності майбутніх фахівців початкової школи. 


\section{ПАРАДИГМАЛЬНИЙ ПІДХІДУ ФОРМУВАННІ КОМУНІКАТИВНОЇ КОМПЕТЕНТНОСТІ}

МАЙБУТНІХ ФАХІВЦІВ ПОЧАТКОВОӤ ШКОЛИ

Виклад основного матеріалу. Кожна наукова парадигма співвідноситься не тільки зі зразками розв'язання дослідницьких завдань, а й з уявленнями про об'єкт науки, що є очевидним, оскільки зразки дослідження, підхід до об'єкта та ракурс його розгляду певною мірою є похідними від онтологічних (закономірностей буття) характеристик об'єкта дослідження, уявлення вчених про які можуть істотно відрізнятися. Парадигма неможлива без чітко визначеної точки зору, концепції чи теорії, навколо якої будується наукове дослідження. Вона легітимізує певні методи, поняття, факти, дослідницькі підходи й принципи наукового знання. Парадигма має яскраво виражений праксіологічний i прагматичний аспекти. Перший стосується кола питань “що і як вивчати?”, другий -“навіщо, з якою метою?" [5, 18-26].

Під освітньою парадигмою розуміється сукупність ключових положень та ідей, які визнані педагогічною спільнотою в конкретний період і $\epsilon$ фундаментом наукових розробок. Формування парадигм освіти відбувається у процесі освоєння людством різних способів взаємодії зі світом. Кожна 3 парадигм відповідає тому чи тому сприйняттю світу як педагогічного об'єкта. Терміном “освітня парадигма” позначають як сукупність найзагальніших уявлень щодо принципів організації освітніх систем, так і спосіб діяльності конкретного педагогічного співтовариства певної епохи [4, 2]. Парадигму не можна декларативно вводити, бо вона $\epsilon$ констатацією певного способу життя, статусних положень ії суб'єктів, характеристикою взаємин усіх систем, що існують у просторово-часовому розумінні. У зв'язку з цим стає очевидним, що парадигма - це метахарактеристика динамічної системи, компонентами якої є суб'єкт-суб'єктні, суб'єкт-об'єктні відносини. Відомо, що парадигма має момент зародження, момент становлення та момент завершення. Зміна однієї парадигми іншою зумовлена, передовсім зміною суспільноекономічної формації, коли складається певна система цінностей, установок, утілюються нові ідеали в освітню систему. Проте постає питання: повинні співвідноситися парадигми між собою, чи можлива їх взаємодія в рамках однієї наукової галузі?

Основна місія освіти на кожному історичному етапі змінювалася залежно від прийнятої людським співтовариством системи цінностей разом $з$ уявленнями про те, за якими законами здійснюється розвиток людини за допомогою освіти. Це визначало зміст, форми й методи навчання та виховання, педагогічне мислення, позицію педагогів та учнів у комунікативному процесі, сам уклад життя освітніх закладів, інакше кажучи, сутність тієї чи тієї освітньої парадигми.

Термін “парадигма" досить часто почали використовувати в другій половині ХХ ст. У результаті відбулося деяке “розмивання" початкового змісту i, як результат, у багатьох дослідженнях під парадигмою почали розуміти нові підходи в навчанні, а іноді, просто нові методи навчання. Як наслідок такого “розмивання" кордонів поняття почали виділяти безліч різноманітних парадигм у системі освіти: технократичну, біхевіористську, культурологічну, раціоналістичну тощо. Водночас, на наш погляд, усе це -моделі освіти, які можуть бути включені в наявну парадигму. У загальному розумінні зазначеного терміна в процесі розвитку системи освіти на рубежі XX - поч. XXI ст. можна виділити лише дві парадигми: класичну та інноваційну. С. Гончаренко визначає парадигму як теорію (або модель постановки проблем), узяту за зразок розв'язання дослідницьких завдань певним науковимспівтовариством.Принципзагальноприйнятої парадигми - методологічна основа єдності певного наукового співтовариства (школи, напряму), що значно полегшує їхню професійну комунікацію [2, 248].

Під освітньою парадигмою щодо методики викладання циклу предметів початкової школи, готовністю вчителя максимально ефективно реалізовувати комунікативний процес у ній будемо розуміти характерну для зазначеної дидактичної спільноти концепт-модель постановки й розв'язання проблем у галузі початкової освіти, засновану на сукупності досягнень відповідної професійної спільноти. Освіта в XXI ст. покликана бути освітою для всіх. Що далі просувається цивілізація, то більше люди без освіти витісняються за межі умов життя, гідних людини. Тому обмеження права на освіту або ㄲi незадовільна якість ведуть до інтелектуальної й культурної деградації особистості, що є несумісним зі стійким світовим розвитком. У рамках нової освітньої парадигми учня необхідно навчати не суми знань, а способів мислення, розвивати творчі здібності, уміння самостійно шукати нові способи розв'язання завдань, вільно здійснювати діяльність у стандартних i нестандартних ситуаціях. Сучасний освітній процес, розширивши уявлення про учня, активно використовує методики, суть яких можна пояснити афоризмом, висловленим ще в XIX ст. А. Дістервегом: “Поганий учитель підносить істину, гарний навчає її знаходити”.

Особливе значення у сфері педагогічної освіти 


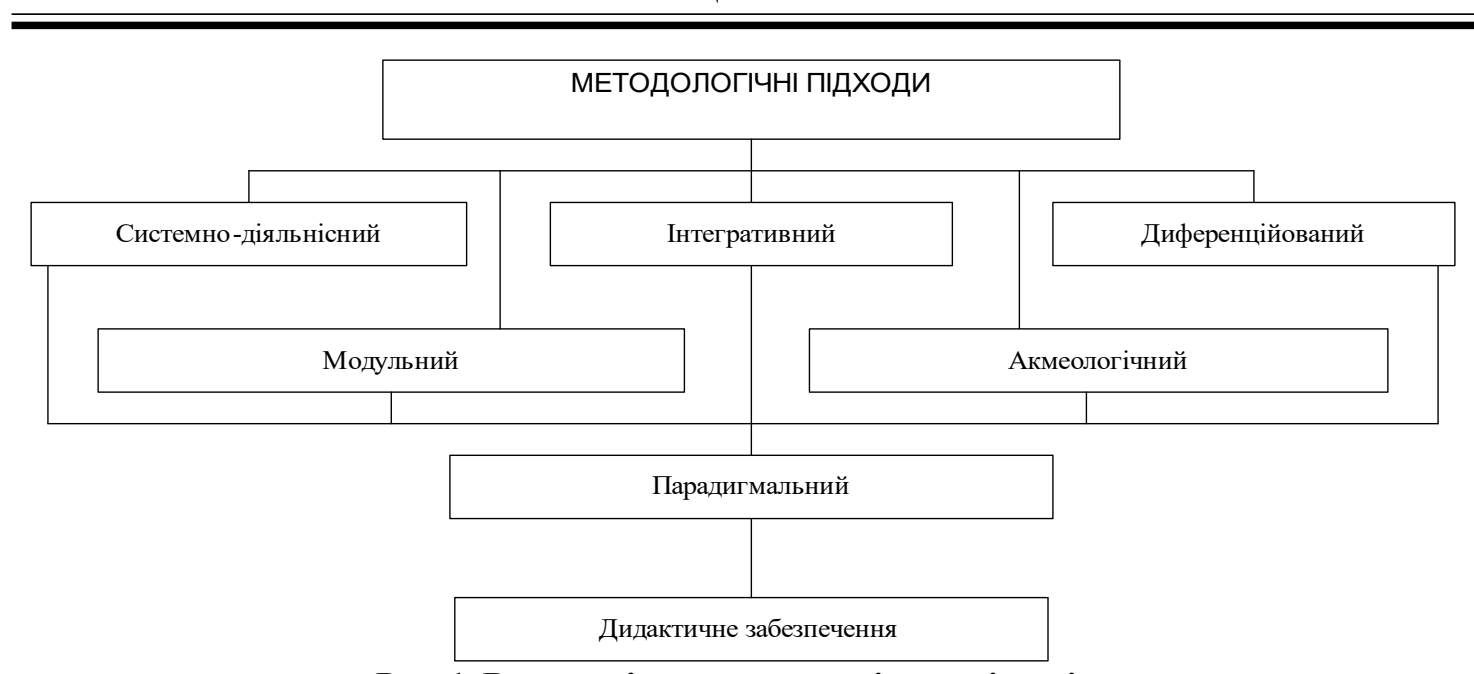

Рис. 1. Взасмозв'язок методологічних підходів

сьогодення набуває інтеграція в області методології (див. рис.1.), що дає змогу забезпечити розробку міждисциплінарних концепцій у системі філософської, соціологічної, екологічної, педагогічної, психологічної та інших наук, заснованих на міждисциплінарній інтеграції. При цьому інтегративне бачення складного об'єкта можливе не тільки через синтез інтегративної методології, а й через взаємодію парадигм у контексті певного простору й часу. Наукове обгрунтування міждисциплінарної теми, якою $€$ комунікативна компетентність майбутнього вчителя у професійній діяльності, засноване на закономірностях функціонування всіх наук, що забезпечують іiі багатоаспектне дослідження. У цьому випадку міждисциплінарність можна вважати не принципом, а провідною методологічною закономірністю, що відрізняється широтою діапазону цілепокладання, коли одночасно поєднуються соціалізація й професіоналізація особистості [1, 3-5].

Зазначимо, що аналіз парадигмальних підходів у формуванні комунікативної компетентності в сучасних умовах дав нам підстави для висновку: спосіб життя, професійної діяльності в освітньому просторі обумовлюється філософією життя в суспільстві, державі, у світі. Комунікативний процес $є$ базовим фактором розвитку особистості. Це означає, що перцептивно-комунікативна діяльність $\epsilon$ вищою формою самовияву особистості як суспільної істоти в умовах соціально-культурної діяльності.

Таким чином, розвиток освітнього простору 3 точки зору його парадигмального базису пов'язаний 3 проявом закономірностей суспільного розвитку, які існують в умовах інтеграції або різного рівня взаємодії, співіснування філософських концепцій, моделей життя, цінностей, установок тощо, що реалізуються в одному просторово-часовому контексті. Для нас також $є$ природним співіснування в освітньому просторі різних парадигмальних підстав, що демонструє не хаос (чого побоюються методологи в педагогічній науці), а радше проголошення й прояв синергетичного погляду на соціальні й освітні явища й процеси. "Переважна частина змін у суспільстві викликана особливим феноменом - перемиканням з однієї парадигми на іншу (зміною парадигми). Усвідомлення людиною парадигм дає змогу краще зрозуміти природу неочікуваних змін” $[6,55]$.

Перехід системи початкової освіти до нової гуманістичної освітньої парадигми (НУШ), що спостерігається сьогодні, вимагає уточнення самого поняття парадигми. Якісно новий та динамічний розвиток економічних, політичних, крос-культурних траєкторій, модифікація цінностей, принципів, суджень, зміна суспільної структури, поява інноваційних технологій стали початком становлення постнекласичної наукової парадигми. Цьому сприяють принципово нові кроки в отриманні, захисті та зберіганні знань (комп'ютеризація), відсутність можливості розв'язання наукових завдань без комплексного застосування знань різних наукових дисциплін, статусу й ролі людини в досліджуваних системах. Спостерігається ще більше посилення математизації дисциплін природничо-наукового циклу, що веде до збільшення рівня їх абстрактності й складності.

У постнекласичній науковій стадії затверджується парадигма цілісності, відповідно до якої Всесвіт, біосфера, ноосфера, суспільство, людина становлять цілісність. Проявом такої цілісності $є$ людина, яка перебуває не за межами об'єкта, що досліджується, а в ньому, вона тільки частина в 


\section{ПАРАДИГМАЛЬНИЙ ПІДХІДУ ФОРМУВАННІ КОМУНІКАТИВНОӤ КОМПЕТЕНТНОСТІ МАЙБУТНІХ ФАХІВЦІВ ПОЧАТКОВОЇ ШКОЛИ}

пізнанні цілого. Результатом такого підходу є конвергенція природних і суспільних наук, тобто принципи сучасного природознавства все більше впроваджуються в гуманітарні науки й навпаки. Ідея синтезу знань, створення універсальної загальнонаукової картини світу стають основними на цьому етапі розвитку науки.

Постнекласична наукова парадигма вимагає комунікації, співпраці й співтворчості професіоналів сфери освіти та навчання взагалі й початкової зокрема. Сучасні вчителі в цій системі повинні стати висококомпетентними, готовими до безперервної самоосвіти, здатними до творчого вдосконалення своїх здібностей, сприйняття самих себе як громадян світу, глобального суспільства, критичного аналізу, осмислення й упровадження в своїй роботі інноваційних технологій як основи успіху в контексті глобалізації всіх сфер діяльності.

Висновки. Зважаючи на викладене вище, зазначимо, що освітня парадигма - це модифікація культурної парадигми, яка становить ціннісносмислову, ідейну підставу освітнього процесу, що домінує на будь-якому етапі розвитку освіти, і яка визначає їі мету, зміст, методи та способи досягнення. Освітня парадигма зумовлює культурні й ціннісні смисли освіти як соціокультурного явища, це культурний зразок, на який орієнтуються суб'єкти освітньої діяльності. 3 цього погляду освітню парадигму слід розглядати як загальний підхід до розв'язання освітянських завдань.

Інакше кажучи, освітня парадигма - це культурний код, що визначає світосприйняття, мислення й поведінку людей, включених до системи освітньої діяльності. Водночас саму освітню парадигму слід розглядати як домінуючу цінність культури освітнього співтовариства в конкретний період часу. Вона виконує нормативну та інтегративну функції. Освітня парадигма задає напрямок, цілі діяльності освітянської спільноти, а також визначає методи їх реалізації. Зрештою, освітня парадигма виступає як ціннісна модель розвитку суспільства. Базовими принципами ціннісної системи гуманістичної парадигми в культурі інформаційного суспільства, на нашу думку, є суб'єктність, толерантність і конструктивне самоствердження особистості. Розгляд сучасних парадигм освіти та підходів до iï організації дає підставу зробити висновок, що сьогодні для людини освіта є не просто певною сумою знань, умінь і навичок, а й психологічною готовністю до безперервного їх накопичення, оновлення, переробки, тобто до постійної самоосвіти, самовиховання, саморозвитку та вдосконалення особистості. Перехід до нової особистісної парадигми - провідна тенденція сучасної освіти, педагогічної свідомості суспільства початку XXI ст., закономірний підсумок розвитку освітнього мислення людини.

У зв'язку з цим парадигма освіти має бути орієнтованою на нові потреби суспільства; вироблення нової системи цінностей у молоді й нових суб'єкт-суб'єктних відносин між викладачем і студентом, коли викладач більше допомагає студентові вчитися, ніж навчає його; формування такої мотивації навчання, яка орієнтована на актуалізацію власної системи цінностей; подолання технократизму освіти; забезпечення освітнього процесу новими методиками із гуманістичним спрямуванням [7].

\section{ЛITЕРАТУРА}

1. Беляева А. П. Междисциплинарная концепция естественно-научного педагогического образования. Эколого-педагогическое образование: проблемы и перспективы развития: сб. материалов науч. педагогич. конф. Санкт-Петербург, 2001. 287 с.

2. Гончаренко С. Український педагогічний словник. Київ : Либідь, 1997. 376 с.

3. Кремень В. Г. Гуманітарна педагогічна парадигма вищої освіти : монографія. Київ : Педагогічна думка, $2007.333 \mathrm{c}$.

4. Клепко С. Ф. Едукологічні репрезентації знань: парадигми освіти. Постметодика. 2011 . № 5 (102). С. 2-9.

5. Савостьянова М. В. Структура та функціональний діапазон парадигмальної науки. Філософія науки: традииї̈ та інноваиії. 2010. № 1 (2). С. 18-26.

6. Семенова А. В. Парадигмальне моделювання у професійній підготовці майбутніх учителів : монографія. Одеса : Юрид. л-ра, 2009. 504 с.

7. Сподін Л. А. Нова освітня парадигма у філософському дискурсі. Філософські науки: зб. наук. праць. 2012 № 66. URL: file:///C:/Users/1/Downloads/ http://archive.nbuv.gov.ua/portal/soc gum/Gileya/ 2012 66/ (дата звернення 27.02.2020).

8. Тюмасева 3. И., Богданов Е. Н., Щербак Н. П. Словарь-справочник современного общего образования: акмеологические, валеологические и экологические тайны. Санкт-Петербург : Питер, 2004. $463 \mathrm{c}$.

\section{REFERENCES}

1. Beliaeva, A. P. (2001). Mezhdystsyplynarnaia kontseptsyia estestvenno-nauchnoho pedahohycheskoho obrazovanyi. [Interdisciplinary concept of natural science pedagogical education]. Ecological and pedagogical education: problems and prospects of development: Proceedings of the scientific and pedagogical conference. St. Petersburg, 287 p. [in Russian].

2. Honcharenko, S. (1997). Ukrainskyi pedahohichnyi slovnyk [Ukrainian Pedagogical Dictionary]. Kyiv, 376 p [in Ukrainian].

3. Kremen, V. H. (2007). Humanitarna pedahohichna 


\section{ЗНАЧЕННЯ ФІЗИЧНОГО ВИХОВАННЯ І СПОРТУ У СОЦАЛІЗАЦЇ ДІТЕЙ ЗОСОБЛИВИМИПОТРЕБАМИ}

paradyhma vyshchoi osvity : monohrafiia [The humanitarian pedagogical paradigm of higher education: a monograph]. Kyiv, 333 p. [in Ukrainian].

4. Klepko, S. F. (2011). Edukolohichni reprezentatsii znan: paradyhmy osvity [Educological representations of knowledge: education paradigms]. Postmethodics. Vol. 5 (102), pp.2-9. [in Ukrainian].

5. Savostianova, M. V. (2010). Struktura ta funktsionalnyi diapazon paradyhmalnoi nauky [Structure and functional range of paradigmatic science]. Philosophy of Science: traditions and innovations. Vol. 1 (2), pp.1826. [in Ukrainian].

6. Semenova, A. V. (2009). Paradyhmalne modeliuvannia u profesiinii pidhotovtsi maibutnikh uchyteliv : monohrafiia [Paradigm modeling in future teacher training: a monograph]. Odessa, 504 p. [in Ukrainian].

7. Spodin, L. A. (2012). Nova osvitnia paradyhma u filosofskomu dyskursi [A new educational paradigm in philosophical discourse]. Philosophical Sciences: collection of scienctific works. Available at: file:///C:/Users/ 1/Downloads/ http://archive.nbuv.gov.ua/portal/soc gum Gileya/2012 66/(Accessed 27 Feb.2020). [in Ukrainian].

8. Tiumaseva, Z. Y., Bohdanov, E. N. \& Shcherbak, N. P. (2004). Slovar-spravochnyk sovremennoho obshcheho obrazovanyia: akmeolohycheskye, valeolohycheskye y ekolohycheskye tainy [Dictionary-reference book of modern general education: acmeological, valeological and ecological secrets]. St. Petersburg, 463 p. [in Russian].

Стаття надійшла до редакції 23.12.2020

УДК: 376.015.31:796

DOI:

Наталія Мукан, доктор педагогічних наук, професор кафедри педагогіки та інноваційної освіти Національного університету “Львівська політехніка" Лариса Козіброда, кандидат наук з фізичного виховання та спорту, доцент кафедри фізичного виховання Національного університету “Львівська політехніка"

\section{ЗНАЧЕННЯ ФІЗИЧНОГО ВИХОВАННЯ І СПОРТУ У СОЦІАЛЗАЦЇ̈ ДІТЕЙ З ОСОБЛИВИМИ ПОТРЕБАМИ}

У статті окреслено значення фізичного виховання і спорту у соиіалізації дітей з особливими потребами. Встановлено, що фізичне виховання і спорт мають великі можливості у процесі соиіалізачії учнів з особливими освітніми потребами. Підтверджено, що велика кількість фізичних вправ і варіативність їх виконання дає змогу проводити відбір дочільних поєднань для кожного окремого випадку. Це обумовлює перевагу засобів фізичного виховання. 3'ясовано, що приниипово новим для теорії та практики занять з дітьми з особливими освітніми потребами є посилення педагогічного аспекту корекиійного впливу на основі врахування єдності біологічних, фізичних, психологічних і соціальних властивостей особистості дитини. Усе ие складає основу для ефективної організації фізичного виховання під час інклюзивного навчання дітей з особливими освітніми потребами.

Ключові слова: фізичне виховання; спорт; фізична культура; інклюзивне фізичне виховання; діти з особливими потребами.

Jim. 19.

Nataliya Mukan, Doctor of Sciences (Pedagogy), Professor of the Pedagogy and Innovative Education Department, Lviv Polytechnic National University

Larysa Kozibroda, Ph.D.(Physical Education and Sport), Associate Professor of the Physical Education Department, Lviv Polytechnic National University

\section{THE ROLE OF PHYSICAL EDUCATION AND SPORT IN SOCIALIZATION OF CHILDREN WITH SPECIAL NEEDS}

Being a particular type of the person's activity, physical culture is significant factor for socialization. It should be indicated that in the system of cultural universal values of people, high level of health and physical condition largely determine the possibilities to master other values becoming the basis for socialization. From this respect, the scientific works relevant to the problem of consideration focus on the search of the most appropriate means and methods for physical education and sport that increase the efficiency of the process of the person's socialization. The article outlines the role of physical training and sport in socialization of children with special needs. It has been indicated, that physical education and sport provide great opportunities in the process of socialization of children with special educational needs. It has been testified, that a great number of physical exercises and variation in their exercising make it possible to select the appropriate combination for each occasion. 